\title{
Myocardial damage after continuous aerobic and anaerobic exercise in rats
}

\author{
Rostika Flora, ${ }^{1}$ Frans Ferdinal, ${ }^{2}$ Bethy S. Hernowo, ${ }^{3}$ Septelia I. Wanandi, ${ }^{4}$ Mohamad Sadikin, ${ }^{4}$ Hans-Joachim \\ Freisleben $^{5}$ \\ ${ }^{1}$ Faculty of Medicine, Universitas Sriwijaya, Palembang, Indonesia \\ ${ }^{2}$ Faculty of Medicine, Universitas Tarumanegara, Jakarta, Indonesia \\ ${ }^{3}$ Faculty of Medicine, Universitas Padjajaran, Bandung, Indonesia \\ ${ }^{4}$ Department of Biochemistry and Molecular Biology, Faculty of Medicine, Universitas Indonesia, Jakarta, Indonesia \\ ${ }^{5}$ Medical Research Unit, Faculty of Medicine, Universitas Indonesia, Jakarta, Indonesia
}

\begin{abstract}
Abstrak
Latar belakang: Aktivitas fisik sangat dianjurkan dalam program pencegahan, pengobatan, dan rehabilitasi, yang bertujuan untuk mempromosikan kesehatan khususnya kesehatan kardiovaskular. Selain meningkatkan fungsi jantung, ternyata aktivitas fisik juga dapat mengakibatkan kematian mendadak. Pada atlet kematian mendadak sering kali terjadi saat pertandingan olahraga dengan penyebab terbanyak adalah infark miokard. Diduga, pola latihan tanpa hari istirahat turut berperan dalam terjadinya kerusakan otot jantung dan kematian mendadak dalam pertandingan. Penelitian ini bertujuan untuk mempelajari adaptasi otot jantung terhadap aktivitas fisik aerobik dan anaerobik yang dilakukan setiap hari tanpa hari istirahat.
\end{abstract}

Metode: Jaringan otot jantung berasal dari tikus yang diberi aktivitas fisik aerobik dan anaerobik menggunakan treadmill selama 1,3,7 dan 10 hari tanpa hari istirahat. Kemudian dilakukan analisis gas darah dan pemeriksaan hematologi sebagai parameter hipoksia dan adaptasi sistemik tubuh terhadap aktivitas fisik, dan gambaran histopatologi otot jantung sebagai parameter terjadinya kerusakan sel otot jantung.

Hasil: Hasil penelitian menunjukkan bahwa aktivitas fisik aerobik dan anaerobik mengakibatkan terjadinya hipoksia sistemik dan menimbulkan respon adaptasi. Kerusakan sel otot jantung terjadi pada hari ke-10 pada kedua kelompok perlakuan, dengan tingkat kerusakan yang lebih berat pada kelompok aktivitas fisik anaerobik. Tingkat protein jaringan pada kelompok anaerobik meningkat secara progresif pada hari ke-10.

Kesimpulan: Aktivitas fisik mengakibatkan terjadinya hipoksia dan adaptasi sistemik. Aktivitas fisik aerobik dan anaerobik yang dilakukan selama 10 hari tanpa hari istirahat mengakibatkan kerusakan sel otot jantung. (Med J Indones. 2013;22:209-14. doi: 10.13181/mji.v22i4.601)

\begin{abstract}
Background: Regular physical activity is highly recommended in preventive, curative, and rehabilitative programs in order to promote health, especially cardiovascular health. However, physical activity can also cause sudden death. In athletes, sudden death may occur during sport competitions, with myocardial infarction as the most common etiology. It is suspected that continuous training without any rest-day play a role in cardiac muscle damage and sudden death during competition. Our study was aimed to learn about cardiac muscle adaptation on continuous aerobic and anaerobic physical activity without any rest-day.
\end{abstract}

Methods: The specimens in our study were cardiac muscle tissue obtained from rats that had performed aerobic and anaerobic physical activity on treadmill for $1,3,7$, and 10 days without any rest-day. Blood gas analysis and hematological assessment were used as parameters of systemic adaptation to hypoxia during physical activity. Moreover, histopathology of cardiac muscle tissue was performed as parameter for cardiac muscle damage.

Results: The results showed that aerobic and anaerobic physical activity caused a systemic hypoxic condition and triggered adaptation responses. Cardiac muscle damage occurred on the 10th day in both treatment groups, with more severe damage observed in the group with anaerobic physical activity. The tissue protein level in the anaerobic group increased progressively on the 10th day.

Conclusion: Physical activity may result in hypoxia and systemic adaptation. Aerobic and anaerobic physical activities performed for 10 days without any rest-day may cause cardiac muscle damage. (Med J Indones. 2013;22:209-14. doi: 10.13181/mji.v22i4.601)

Keywords: Cardiac muscle, cardiac muscle damage, histopathology, physical activity

Exercise is regular physical activity within a certain period of time and intensity, which aims to increase physical performance and to keep the body healthy and fit. In addition to maintaining physical fitness, physical exercise is recommended for preventive, curative, and rehabilitative programs in an effort to improve health, especially of the heart. Considering energy metabolism, there are two forms of exercise, aerobic, and anaerobic. Aerobic condition produces a minimum of $30 \mathrm{~mol}$ ATP by mitochondrial oxidative phosphorylation with glucose from glycogen and free fatty acids as the main metabolic sources of energy. The process depends 
on the availability of molecular oxygen. Anaerobic exercise does not use oxygen in the metabolic process of energy conservation. In the latter case, formation of ATP uses free glucose via glycolysis yielding only 2 mol per mol glucose or replenishment from creatine phosphate via phosphocreatine kinase. ${ }^{2,3}$

Basically, all kinds of physical activity are a mixture of aerobic and anaerobic metabolic activities, which only differ in their percentages. For example, tennis games consist of $25-30 \%$ aerobic and $70-75 \%$ anaerobic activities. Sprinting to catch the ball and hit the ball vigorously are anaerobic activities. There is no oxygen intake while sprinting, intake of oxygen occurs after finishing the sprint. ${ }^{3}$ If we assume that there is a cardiac muscle dysfunction, the oxygen supply may not meet cardiac muscle demand when sprinting and will cause sudden heart attack. Tennis players may feel chest pain caused by sudden heart attack, but since they want to finish their game desperately, they ignore the pain; in extreme cases, this condition can cause further and larger cardiac muscle cell damage and may lead to sudden death.,3

Hence, exercise can benefit cardiovascular health and function, but it may also cause sudden death. In athletes, sudden death often occurs during sport competitions. A retrospective study on athletes' deaths between 1990 and 1997 in Norway showed that about 23 sudden deaths occurred in athletes aged 17-34 years and the main cause (48\%) was cardiac muscle infarction. ${ }^{4}$ Another study from Ireland evaluating the data of athletes' deaths from 1987 to 1996 reported that 51 sudden death cases occurred in athletes at an average age of 48 years and the main cause $(82 \%)$ was coronary atherosclerosis. ${ }^{5}$ It has been suspected that continuous training without any rest-day for competition plays a role in cardiac muscle damage and in sudden deaths occurring during the competition.

Therefore, further research is required to recognize the effect of continuous aerobic and anaerobic physical activity without any rest-day on cardiac muscle histopathology features. Using experimental animals such as rats as research models is the best way to develop research programs in order to gain more knowledge about tissue features at cellular level in aerobic and anaerobic physical activity loads without any rest- day.

Recently, we reported the correlation between vascular endothelial growth factor (VEGF) and hypoxia inducible factor $1-\alpha($ HIF $1-\alpha)$ in cardiac muscle of wistar rats during aerobic and anaerobic exercise. ${ }^{1}$ In this study, we show histological features and protein levels of rat myocardium at the same exercise conditions of continuous aerobic and anaerobic physical activity with no rest-day.

\section{METHODS}

This experimental animal study was conducted in the animal house of the Faculty of Medicine, Universitas Indonesia between August 2009 and August 2010 as described by Flora, et al. ${ }^{1}$ Forty five male Wistar rats, 6-8 weeks old weighing 80-100 g were assigned randomly to a control group (P1) and eight exercise groups (P2-P9). Some rats died during exercise, some rats were lazy, not running properly and not following the exercise protocol on the treadmill, amounting to totally 18 dropped-out rats. At the end, each group provided data of three rats $(n=3)$, which was calculated as the animal requirement of our study. Four groups performed aerobic (P2-P5) and four anaerobic (P6-P9) exercise. For aerobic exercise a treadmill at a speed of $20 \mathrm{~m} / \mathrm{min}$ was used continuously for 30 minutes and for the groups performing anaerobic exercise the speed was adjusted to $35 \mathrm{~m} / \mathrm{min}$ continuously for 20 minutes. Exercise on the treadmill was performed for $1,3,7$, and 10 days, without any rest-day. The experimental procedure for aerobic and anaerobic exercise was adapted from the method of Fahrenia, ${ }^{6}$ which in turn is based on the method of Soya, et al. ${ }^{7}$ All rats were acclimated to the treadmill for 1 week by exposing them to the apparatus moving at low speed.

The study was approved by the Ethical Committee of the Faculty of Medicine, Universitas Indonesia. At the end of the experimental period, the rats were decapitated and their hearts were excised. Cardiac muscle tissue was stored at $-70^{\circ} \mathrm{C}$ until processed.

After each experiment, blood and tissue specimens from cardiac muscle were collected for blood gas analysis and for histology and protein determination, respectively. Blood gas analysis was carried out with heparinized aortic blood using a Corning 165 Blood Gas Analyzer. The values of oxygen partial pressure $\left(\mathrm{PO}_{2}\right)$, oxygen saturation $\left(\mathrm{Sat} \mathrm{O}_{2}\right), \mathrm{PCO}_{2}$ and $\mathrm{pH}$ were presented in Flora, et al. ${ }^{1}$ Further hematological data were obtained from a Sysmex KX21 Hematology Analyzer using venous EDTA-blood (data not shown).

The determination of protein levels and blood gas analysis were conducted in the laboratory of the Department of Biochemistry and Molecular Biology, Faculty of Medicine, Universitas Indonesia.

\section{Measurement of protein levels}

Protein levels of cardiac muscle tissues were measured spectrophotometrically at $\lambda=280 \mathrm{~nm}$ with bovine serum albumin (BSA) as standard. Aliquots of 0.1 
gram muscle tissue specimen were placed in $1 \mathrm{~mL}$ of 0.1 M PBS, $\mathrm{pH}$ 7.4. The specimens were ground by a tissue grinder under cold condition. The homogenates were centrifuged at $5000 \mathrm{rpm}$ for 10 minutes and the supernatant stored at $-70^{\circ} \mathrm{C}$. For measurement, the supernatants were diluted 20 times and the absorbance measured versus the BSA standard curve to determine protein levels.

\section{Histological evaluation}

Histological evaluation was done in the laboratory of the Department of Pathological Anatomy, Faculty of Medicine, Universitas Padjajaran, Bandung. Cardiac muscle tissues were stained by using hematoxylin and eosin (HE). The tissue preparations were evaluated by light microscopy and categorized as normal, hypertrophic, ischemic, or infarcted: ${ }^{8-10}$ A) Normal: no signs of hyperthrophy, ischemia and infarction; B) Hypertrophic: cardiac muscle cells looked larger and the fibers of cardiac muscle showed disarray ${ }^{8} \mathrm{C}$ ) Ischemic: mitochondria appeared dark, sarcolemma damaged, chromatin nuclei condensed and on the edge, erythrocytes were trapped in the capillaries; ${ }^{9}$ D) Infarcted: heart muscle fibers were damaged, underwent streching, appeared wavy, were seen rarely, and tearing occured. ${ }^{10}$

\section{Statistics}

The research data were processed using SPSS 17.0 software. ANOVA was conducted to examine mean differences between the groups with significance level of $\mathrm{p}<0.05$.

\section{RESULTS}

\section{Blood gas analysis}

Oxygen partial pressure $\mathrm{PO}_{2}$ was reduced in all exercise groups vs controls, highly significant in the average of anaerobic groups and not significant in the average of aerobic groups. ${ }^{1}$ The latter value $(66.5 \mathrm{mmHg})$ was almost two-fold higher than in the anaerobic groups (34.04 mmHg). Oxygen saturation was also significantly reduced in the exercise groups vs controls, highly significant in anaerobic and significant in aerobic groups.

Carbondioxide partial pressure $\left(\mathrm{PCO}_{2}\right)$ was increased in all anaerobic and aerobic groups. The anaerobic average $(59.93 \mathrm{mmHg})$ was slightly higher than the aerobic value $(56.86 \mathrm{mmHg})$. However, the latter differed significanly from controls $(37.93 \mathrm{mmHg}$ ) because of its low standard deviation (SD) of \pm 4.92 , whereas the high $\mathrm{SD}$ of \pm 12.92 in the anaerobic average made it not significant. The $\mathrm{pH}$ values were lower in all exercise groups than in controls $(\mathrm{pH}$ 7.1) and slightly lower in the anaerobic $(\mathrm{pH}$ 6.9) than in the aerobic average ( $\mathrm{pH}$ 7.0). All differences in $\mathrm{pH}$ values between the groups were statistically not significant $^{1}$ (Table 1).

\section{Level of tissue protein}

At baseline, both control and exercise groups had similar protein levels; further development during exercise was unclear and diffences not significant. A trend was seen in the anaerobic group on day 10, where cardiac protein levels were increased as compared to control and aerobic groups (data not shown).

Table 1. Blood gas analysis: partial oxygen pressure, oxygen saturation, partial carbondioxide pressure and $\mathrm{pH}$ under aerobic and anaerobic conditions

\begin{tabular}{lcccccccc}
\hline Parameter & \multicolumn{2}{c}{$\mathrm{PO}_{2}[\mathrm{mmHg}]$} & \multicolumn{2}{c}{$\mathrm{Sat}_{2}[\%]$} & \multicolumn{2}{c}{$\mathrm{PCO}_{2}[\mathrm{mmHg}]$} & & $\mathrm{pH}$ \\
\hline Condition & anaerobic & aerobic & anaerobic & aerobic & anaerobic & aerobic & anaerobic & aerobic \\
\hline Control & \multicolumn{2}{c}{$90.23 \pm 1.357$} & \multicolumn{2}{c}{$91.40 \pm 2.046$} & $37.93 \pm 3.724$ & & $7.07 \pm 0.048$ \\
Day 1 & $35.83 \pm 14.03$ & $36.78 \pm 1.50$ & $39.45 \pm 16.14$ & $34.28 \pm 4.83$ & $44.13 \pm 4.92$ & $52.88 \pm 15.53$ & $6.86 \pm 0.101$ & $6.94 \pm 0.029$ \\
Day 3 & $50.77 \pm 1.03$ & $76.60 \pm 2.04$ & $71.77 \pm 10.19$ & $40.53 \pm 19.04$ & $50.30 \pm 7.48$ & $52.07 \pm 3.37$ & $6.97 \pm 0.054$ & $6.94 \pm 0.033$ \\
Day 7 & $20.77 \pm 6.32$ & $84.67 \pm 4.26$ & $32.57 \pm 3.84$ & $68.63 \pm 0.45$ & $71.63 \pm 10.79$ & $58.13 \pm 2.33$ & $7.02 \pm 0.059$ & $7.05 \pm 0.019$ \\
Day 10 & $28.78 \pm 8.30$ & $67.93 \pm 32.56$ & $25.45 \pm 3.10$ & $66.73 \pm 3.31$ & $73.66 \pm 21.11$ & $64.37 \pm 8.47$ & $6.81 \pm 0.173$ & $6.98 \pm 0.014$ \\
Average & $34.04 \pm 11.03$ & $66.50 \pm 18.15$ & $42.40 \pm 17.71$ & $52.54 \pm 15.31$ & $59.93 \pm 12.92$ & $56.86 \pm 4.92$ & $6.92 \pm 0.084$ & $6.98 \pm 0.045$ \\
Significance & high s. & n.s. & high s. & signific & n.s. & high s. & n.s. & n.s. \\
p vs C & 0.000 & 0.149 & 0.009 & 0.017 & 0.088 & 0.005 & 0.105 & 0.137 \\
\hline
\end{tabular}

Blood gas analysis was routinely conducted ( $\mathrm{n}=3$ in each group), $\mathrm{PO}_{2}=$ partial oxygen pressure, $\mathrm{Sat}_{2}=$ oxygen saturation, $\mathrm{PCO}_{2}=$ partial carbondioxide pressure, $\mathrm{C}=$ control, signific $=$ significant, $\mathrm{n} . \mathrm{s} .=$ not significant, high $\mathrm{s} .=$ high significance 


\section{Histology of myocardium}

Histology of cardiac muscles on day 1 did not show any signs of hypertrophy, ischemia, or infarction. On day 3 , there were signs of cardiac muscle cell hypertrophy. Further histological examination revealed signs of cardiac muscle cell ischemia on day 7 and of infarction on day 10 in both groups (Figures 1 and 2).

To compare the aerobic and anaerobic histology, we see differences between figure $1 \mathrm{c} / \mathrm{e}$ and $2 \mathrm{c} / \mathrm{e}$ where figure 2 c/e should more pronounced changes whereas figure $2 \mathrm{~d}$ does not show any significant difference with figure $1 \mathrm{~d}$.

\section{DISCUSSION}

The treadmill exercise model applied in our study led to a rapid decrease in partial oxygen pressure on the first day of exercise, both in anaerobic and aerobic condition. Whereas the aerobic exercise group quickly recovered in the course of the experiments, $\mathrm{PO}_{2}$ stayed low in anaerobic condition. ${ }^{1}$ This indicates well that we used a valid exercise model differentiating between aerobic and anaerobic conditions. The other parameters of hypoxic or normoxic condition shown in Flora, et $\mathrm{al}^{1}$ exerted similar trends, although not as clear as partial oxygen pressure; oxygen saturation fluctuated but followed the same pattern. Partial carbondioxide pressure showed an opposite trend, it increased under exercise, more in anaerobic than in aerobic condition. Decrease of $\mathrm{pH}$ level was the fourth indicator of hypoxic condition under exercise measured in our study. Its decrease was slightly more observed in anaerobic than in aerobic condition.

Statistical significance should not be overestimated in this context, first the model was not absolute, i.e., neither fully anaerobic on one hand, nor fully aerobic on the other. Second, the numbers of our experimental animals and thus of our samples were low $(n=3)$ and third, individual fluctuations in some groups were considerable. However, these shortcomings do not alter the total picture of a valid model for anaerobic and aerobic exercise. ${ }^{6,7}$

In accordance with blood gas analysis, the cardiac protein level at baseline, both in control and exercise groups were similar. On day 3 protein level tended to increase in the aerobic groups, then gradually decreased to day 10 , whereas in the anaerobic groups, protein level was highest on day 10. Progressive protein increase is due
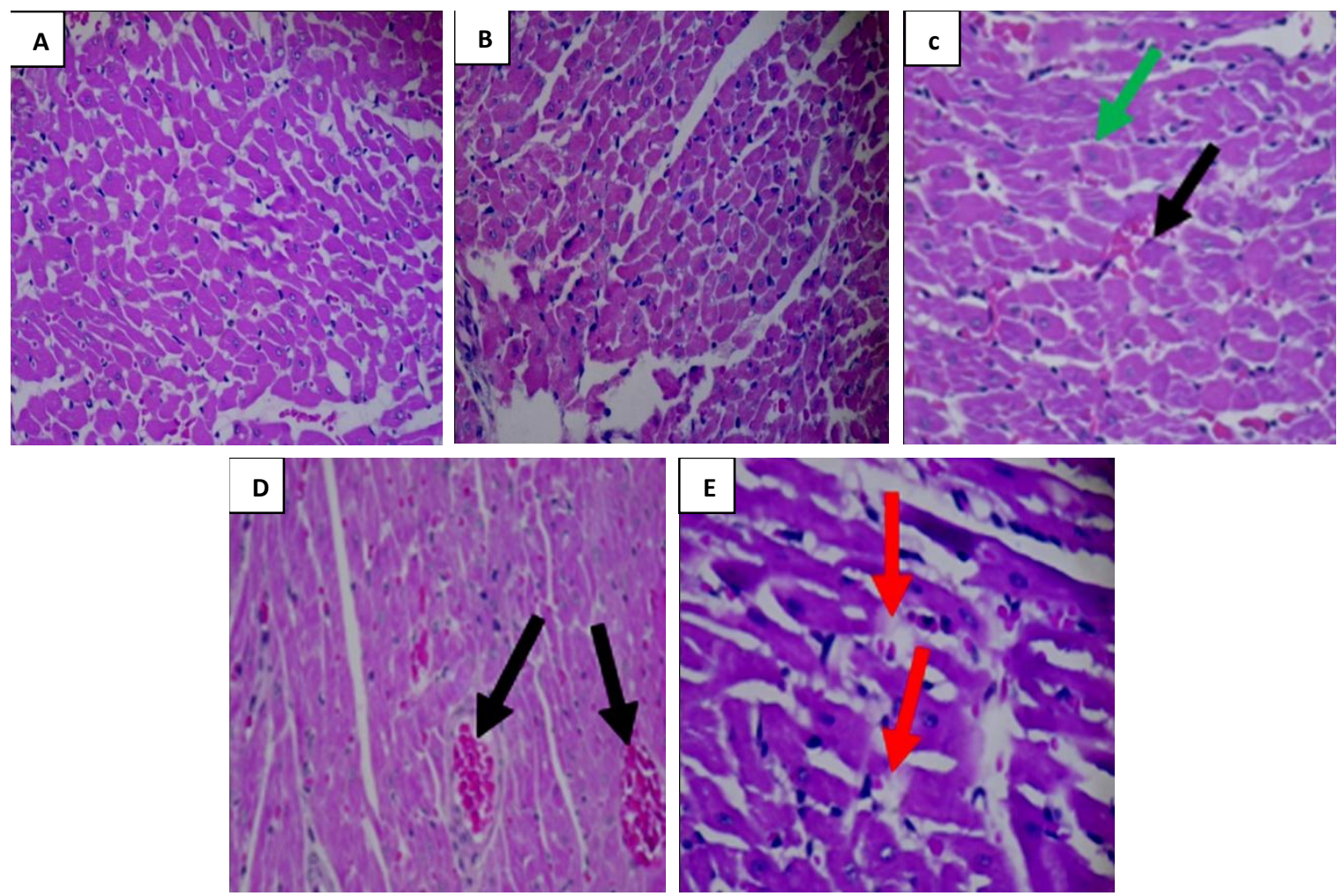

Figure 1. Histology of aerobic groups; A, control (normal); B, day 1 (normal); C, day 3 (hypertrophic, the arrows denote cardiac muscle cells looking larger and the fibers of cardiac muscle showing disarray); $D$, day 7 (ischemic, the arrows denote mitochondria appearing dark, sarcolemma damaged, chromatin nuclei condensed and on the edge, erythrocytes trapped in the capillaries); E, day 10 (infarcted, the arrows denote heart damaged muscle fibers, which underwent stretching, looking wavy, seen rarely, and tearing occured) 

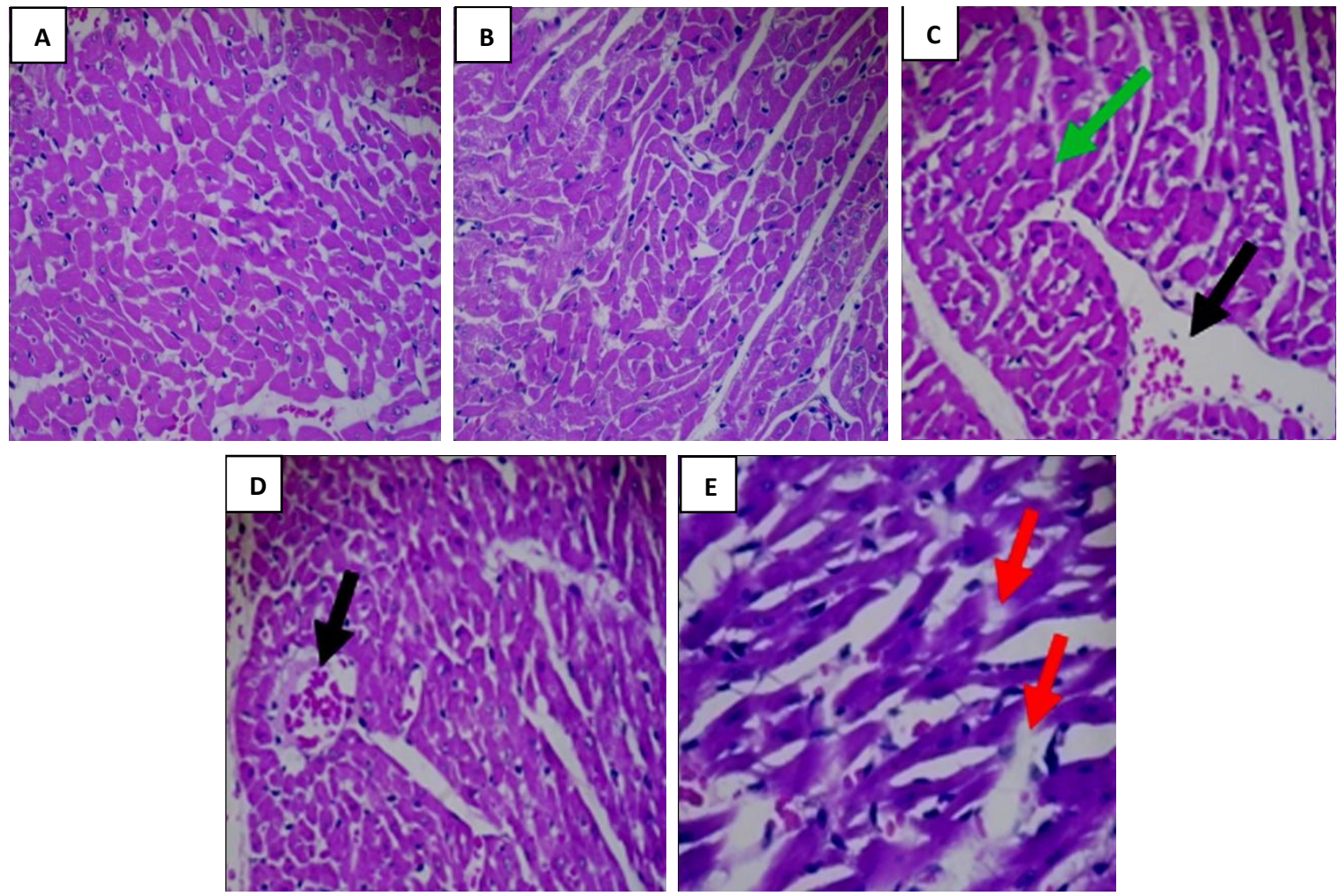

Figure 2. Histology of anaerobic groups; A, control (normal); B, day 1 (normal); $C$, day 3 (hypertrophic, the arrows denote cardiac muscle cells looking larger and the fibers of cardiac muscle showing disarray); $D$, day 7 (ischemic, the arrows denote mitochondria appearing dark, sarcolemma damaged, chromatin nuclei condensed and on the edge, erythrocytes trapped in the capillaries); E, day 10 (infarcted, the arrows denote damaged heart muscle fibers, which underwent stretching, looking wavy, seen rarely, and tearing occured)

to heart muscle cell damage. Injured cardiac muscle cells release proteins into circulation and some these proteins can be used to specifically diagnose cardiac muscle damage. We did not measure specific marker proteins or enzyme activities, but the general protein increase up to day 10 of anaerobic exercise indicates increased damage of cardiomyocytes, whereas in aerobic exercise the course rather mirrored the process of adaptation.

Histology of cardiac muscles on day 1 did not show any signs of hypertrophy, ischemia, or infarction. On day 3 , there were signs of cardiac muscle hypertrophy. Such histological finding demonstrated that there was an adaptation response to increased heart load during exercise. Continuous physical activity will cause greater muscle mass and volume, in other words, heart muscle hypertrophy called athlete's heart, which is considered a normal adaptation response. Physical load will cause left ventricle (LV) to pump harder, which may change its size. The changes of ventricle size depend on the type of physical activity or exercise. ${ }^{11}$

Aerobic or endurance type of exercise will increase LV filling; first, it will increase plasma volume and therefore, also LV end-diastolic volume (increased preload).
Next, the duration of diastolic filling will increase. The increase of plasma volume and diastolic filling duration will change the end-diastolic size of LV.

On the contrary, during anaerobic or resistance type of exercise, LV has to work hard to push through high pressure circulation (increased afterload). To compensate increased afterload, myocardium will increase the thickness of the muscle in order to enhance contraction power. Increase of cardiac muscle mass is a direct adaptation to anaerobic or resistance type of exercise.

In fact, increased thickness of the cardiac muscle wall (and thus, increased muscle mass) will not only be found in anaerobic or resistance type, but also in the aerobic or endurance type of exercise, as recent studies reported. ${ }^{11}$

Cardiac muscle cell hypertrophy is considered a mechanism of adaptation to increase muscle contractility and decrease ventricle wall pressure. ${ }^{12}$ Long-lasting hypertrophy will decrease ventricle function and thus, will turn into mal-adaptation; subsequently, remodeling of the ventricle will occur. Ventricle remodeling is a transition phase towards ventricle dilation and heart failure. $^{13}$ 
Histological examination revealed signs of cardiac muscle ischemia on day 7 and infarction on day 10 . Hypertrophy of cardiac muscle will cause capillary compression through increased extravascular pressure leading to ischemia. Erythrocytes are trapped in compressed capillary vessels, which along with the ischemic condition will disrupt capillaries to become more permeable to erythrocytes and increase local oxygen supply. ${ }^{9}$

On 10 day, in aerobic and anaerobic groups, cardiac muscle fibers were stretched. This lengthening of muscle fibers may occur as an adaptation response to increased preload in order to maintain the LV enddiastolic volume. Histopathology on day 10 found cardiac muscle damage both in aerobic and anaerobic groups, certainly caused by heavy exercise load without any rest-day. The damage in the anaerobic group were more severe than in the aerobic group.

Every cardiac muscle cell has $\mathrm{Z}$ lines that separate sarcomeres from each other. High intensity exercise will lead to over-stretched muscle fibres, Z-line disruption and protein leakage from cardiomyocytes, such as myoglobin and creatinekinase. ${ }^{14,15}$ During heavy load or high intensity physical activity, cardiac muscle cell leakage occurred due to increased cell membrane (= sarcolemma) damage and permeability. ${ }^{6}$

In conclusion, aerobic and anaerobic exercise performed for 10 days without any rest-day may cause damages of cardiomyocytes and whole cardiac muscle. These damages were more severe with anaerobic exercise in our animal model.

\section{REFERENCES}

1. Flora R, Freisleben H-J, Ferdinal F, Wanadi SI, Sadikin M. Correlation of hypoxia inducible factor- $1 \alpha$ and vascular endothelium growth factor in rat myocardium during aerobic and anaerobic exercise. Med J Indones. 2012;21(3):133-40.
2. Åstrand PO, Rodahl K, Dahl HA, Stromme SB. Textbook of Work Physiology. Physiological bases of exercise. $4^{\text {th }}$ ed. Human Kinetics, Champaign, IL; 2003. p. 237-312.

3. Kusmana D. Olahraga untuk orang sehat dan penderita penyakit jantung. $2^{\text {nd }}$ ed. Jakarta: FKUI; 2006. Indonesian.

4. Solberg EE, Gjertsen F, Haugstad E, Kolsrud L. Sudden death in sport among young adults in Norway. Eur J Cardiovasc Prev Rehabil. 2010;17(3):337-41.

5. Quigley AF, Kapsa RM, Esmore D, Hale G, Byrne E. Mitochondrial respiratory chain activity in idiopathic dilated cardiomyopathy. J Card Fail. 2000;6(1):47-55.

6. Fahrenia RR. Ekspresi Gen mioglobin dan serum kreatinfosfokinase pada aktivitas fisik aerobik dan anaerobik sebagai indikator hipoksia dan kerusakan jantung otot tikus wistar [dissertation]. Mount Pleasant (MI): Universitas Padjadjaran; 2009. Indonesian.

7. Soya H, Mukai A, Deocaris CC, Ohiwa N, Chang H, Nishijima $\mathrm{T}$, et al. Threshold-like pattern of neuronal activation in the hypothalamus during treadmill running: establishment of a minimum running stress (MRS) rat model. Neurosci Res. 2007;58(4):341-8.

8. St John Sutton MG, Lie JT, Anderson KR, O’Brien PC, Frye RL. Histopathological specificity of hypertrophic obstructive cardiomyopathy. Myocardial fibre disarray and myocardial fibrosis. Br Heart J. 1980;44(4):433-43.

9. Flameng W, Vanhaecke J, Borgers M. Histology of the postischaemic myocardium and its relation to left ventricular function. Br J Anaesth. 1988;60:14S-22S.

10. Akasaka Y, Morimoto N, Ishikawa Y, Fujita K, Ito K, KimuraMatsumoto M, et al. Myocardial apoptosis associated with the expression of proinflammatory cytokines during the course of myocardial infarction. Mod Pathol. 2006;19(4):588-98.

11. Wilmore JH, Costill DL. Physiology of Sport and Exercise. $3^{\text {rd }}$ ed. Human Kinetics, Champaign, IL; 2004. p. 270-98.

12. Hunt SA, Abraham WT, Chin MH, Feldman AM, Francis GS, Ganiats TG, et al. ACC/AHA guideline update for the diagnosis and management of chronic heart failure in the adult: a report of the American College of Cardiology/ American Heart Association - Task Force on Practice Guidelines. Circulation. 2005;112:e154-235.

13. Selvetalla G, Lembo G. Mechanisms of cardiac hypertrophy. Heart Fail Clin. 2005;1(2):263-73.

14. Montorsi P, Villa M, Dessanai MA. Temporal profile of protein release in myocardial infarction. Heart Metab. 2009;43:31-5.

15. Brancaccio P, Maffulli N, Limongelli FM.. Creatine kinase monitoring in sport medicine. Br Med Bull. 2007;8182:209-30. 